\title{
Effect of Co-administration of Morphine and Cholinergic Antagonists on Y-maze Spatial Recognition Memory Retrieval and Locomotor Activity in Mice
}

\author{
HE Jing ${ }^{1,2}$, CHEN Yan-mei ${ }^{1,2}$, WANG Jian-hong ${ }^{1}$, MA Yuan-ye ${ }^{1, *}$ \\ (1. Laboratory of Primate Neuroscience Research and Key Laboratory of Animal Models and Human Disease Mechanisms, Kunming Institute of Zoology,the \\ Chinese Academy of Sciences, Kunming Yunnan 650223, China; 2. Graduate School of the Chinese Academy of Sciences, Beijing 100049, China)
}

\begin{abstract}
The interaction of morphine and cholinergic system was shown in previous studies. In the present study, we investigated whether morphine would interact with the cholinergic antagonists, scopolamine and atropine in a Y-maze spatial recognition memory. Pre-test treatments of morphine $(5,1.5,0.5 \mathrm{mg} / \mathrm{kg})$, scopolamine $(1,0.1 \mathrm{mg} / \mathrm{kg})$, atropine $(0.5$, $0.1 \mathrm{mg} / \mathrm{kg}$ ) were used in the experiments, relatively high or low doses were paired respectively as co-administration measures. The results showed that co-administration of morphine $0.5 \mathrm{mg} / \mathrm{kg}+$ scopolamine $0.1 \mathrm{mg} / \mathrm{kg}$ and morphine 0.5 $\mathrm{mg} / \mathrm{kg}+$ atropine $0.1 \mathrm{mg} / \mathrm{kg}$ disturbed the inspective exploratory behavior (percent of arm duration) but not the inquisitive behavior (percent of arm visits) of the spatial memory retrieval, while the drugs didn't cause amnesia when single administered of the concerned low doses. Distinct interaction was found between scopolamine and morphine on increasing locomotor activity.
\end{abstract}

Key words: Retrieval; Morphine; Scopolamine; Atropine; Y-maze

\section{吗啡和胆碱能拮抗剂联合给药对小鼠 $\mathbf{Y}$ 迷宫空间记忆提取及活动性的影响 何 静 1,2 , 陈艳梅 ${ }^{1,2}$, 王建红 ${ }^{1}$ ，马原野 1 , * \\ (1. 中国学院昆明动物研究所 灵长类认知实验室, 云南昆明 650223 ; 2. 中国科学院研究生院, 北京 100049)}

摘要: 吗啡和胆碱能系统的相互作用已在多项研究中提到, 本实验想查明吗啡是否能和胆碱能拮抗剂、东莨 宕碱以及阿托品共同作用对小鼠的 $\mathrm{Y}$ 迷宫空间识别记忆提取产生影响。采用测试前腹腔给药的方法, 选用 3 种剂 量的吗啡 $(5 、 1.5 、 0.5 \mathrm{mg} / \mathrm{kg})$, 两种剂量的东莨宕碱 $(1 、 0.1 \mathrm{mg} / \mathrm{kg})$, 以及两种剂量的阿托品 $(0.5 、 0.1 \mathrm{mg} / \mathrm{kg})$, 剂量 由高到低相配对作为联合给药的手段。其结果表明: 1) $0.5 \mathrm{mg} / \mathrm{kg}$ 低剂量吗啡与 $0.1 \mathrm{mg} / \mathrm{kg}$ 低剂量的东莨宕碱, 或 与 $0.1 \mathrm{mg} / \mathrm{kg}$ 低剂量的阿托品联合给药的小鼠, 在记忆提取测试中, 空间探查行为（各臂停留时间百分比）对新 异臂没有偏好, 而新奇探索行为 (各臂访问次数百分比) 仍保持了对新异臂的偏好, 而相应剂量药物单独给药的 小鼠记忆提取均没有被损害；2）吗啡能和东莨宕碱相互作用使小鼠的活动性显著增强。暗示吗啡和胆碱能拮抗剂 对小鼠空间记忆提取的破坏存在一定程度的相互作用。

关键词: 记忆提取; 吗啡; 东莨宕碱; 阿托品; Y 迷宫

中图分类号: Q42; Q959.837 文献标识码: A 文章编号: 0254-5853(2008)06-0613-08

Cholinergic system has been found to play a role in learning and memory (Deutsch, 1971). Cholinergic antagonists, scopolamine and atropine disrupted memory process in various tasks in animals (Meyers, 1965; Patel \& Tariot, 1991; Rupniak et al, 1989; Sunderland et al, 1986), and in human (Christensen et al, 1992; Drachman
\& Leavitt, 1974; Ebert \& Kirch, 1998; Wesnes et al, 1991). Generally, these two drugs have no qualitative difference, as to the signs of peripheral parasympathetic block and an extensive impairment of central nervous system function on human (Ketchum et al, 1973). However when combined with analgesics in

Received date: 2008-07-31; Accepted date: 2008-10-28

Foundation items: National Natural Science Foundation of China (30770700; 30470553)

收稿日期：2008-07-31；接受日期：2008-10-28

基金项目：国家自然科学基金（30770700; 30470553）

“通讯作者 (Corresponding author), E-mail: yuanma0716@vip.sina.com

第一作者（First author）,E-mail: deedee39@21cn.com 
pre-operation sedation and obstetrical amnesia, atropine failed to cause amnesia and potentiation of pentothal narcosis in doses in which scopolamine was effective (Orkin et al, 1956).

Many reports demonstrated that acute administration of opioids impairs cognitive functions in animals (Castellano \& Pavone, 1985; Itoh et al, 1994; Izquierdo, 1980; Schulteis et al, 1988; Stone et al, 1991; Walker et al, 1991). Previous researches suggested that activation of opioid receptors can decrease the function of cholinergic system and cause memory deficit. Muscarinic receptor agonist oxotremorine co-administrated with naloxone significantly improved memory in an one-trial inhibitory avoidance task (Baratti et al, 1984). However the muscarinic antagonist atropine blocked the memory-enhance induced by naloxone (Baratti et al, 1984). Post-training administration of naloxone reversed memory impairment induced by scopolamine in a passive avoidance task and spontaneous alternation tests (Rush, 1986; Walker et al, 1991). Muscarinic agonists could antagonize the memory impairment induced by $\beta$-endorphine (Introini \& Baratti, 1984). Thus, it has been suggested interaction between opiate and cholinergic system.

Since it has been proved that the cholinergic antagonist, scopolamine impaired retrieval of working memory in rats (Beatty et al, 1986), while morphine had an inconsistent effect on memory retrieval in mice (Kahveci et al, 2006; Shiigi \& Kaneto, 1990; Shiigi et al, 1990; Zarrindast et al, 2006), and our previous data showed that morphine impaired the retrieval of spatial recognition memory in a Y-maze (Ma et al, 2007). In the present study, we used the Y-maze to test the effects of co-administration of morphine and cholinergic antagonists, scopolamine, and atropine on spatial recognition memory retrieval. According to the previous studies we hypothesized that the combined administration of morphine and scopolamine/atropine would enhance memory deficit because of the cholinergic system function may be suppressed by both morphine and the muscarinic antagonists. Meanwhile, effects of drugs on the locomotor activity can be tested in the Y-maze as well.

\section{Materials and methods}

\subsection{Animals}

Male ICR mice (24-28g body weight, at age of 8 weeks) from breeding colonies at the Kunming Medical
College were used. They were housed under standard conditions (a 12-hr light/dark cycle with light on from 07:00 to 19:00) and were reared in separate cages (8 per cage). Mice were freely feeding and familiarized with the experimenter and the testing environment for one week before the experiment started. The experiments were conducted in accordance with the Guide for Care and Use of Laboratory Animals (Publication No. 85-23, revised 1985) and were approved by the National Institutes of Health.

\subsection{Drugs}

Morphine hydrochloride $(10 \mathrm{mg} / \mathrm{mL}$, Shenyang Pharmaceutical Factory), scopolamine hydrobromide (0.3 mg/mL, Shanghai Harvest Pharmaceutical Co), atropine sulfate $(0.5 \mathrm{mg} / \mathrm{mL}$, Tianjin Pharmaceutical Factory), were dissolved in the saline.

\subsection{Behavioral apparatus}

The Y-maze was made of grey plexiglass or wood, covered with black paper, and consisted of three arms with an angle of $120^{\circ}$ between each two arms. Each arm was $8 \mathrm{~cm} \times 30 \mathrm{~cm} \times 15 \mathrm{~cm}$ (width $\times$ length $\times$ height $)$. The three identical arms were randomly designated: Start arm, in which the mouse started to explore (always open); Novel arm, which was blocked at the 1st trial, but open at the 2nd trial; and the other arm (always open).

The maze was placed in a separate room with enough light. The floor of the maze was covered with sawdust, which was mixed after each individual trial in order to eliminate olfactory stimuli. Visual cues were placed on the walls of the maze.

The Y-maze test consisted of two trials separated by an inter-trial interval (ITI) to assess spatial recognition memory. The first trial (training) was 10 min duration and allowed the mouse to explore only two arms (start arm and the other arm) of the maze, with the third arm (novel arm) blocked. After a $1 \mathrm{~h}$ ITI (Ma et al, 2007), the second trial (retention) was conducted, during which all three arms were accessible and novelty vs. familiarity was analyzed through comparing behavior in all three arms. For the second trial, the mouse was placed back in the maze in the same starting arm, with free access to all three arms for $5 \mathrm{~min}$. By using a ceiling-mounted CCD camera, all trials were recorded on a VCR. Video recordings were later analyzed. The number of entries and time spent in each arm were to be analyzed; data were also expressed as percentage of performance in all arms during the 5-min-retention test (Akwa et al, 2001).

Because memory retention in the Y-maze test did 
not last longer than a few hours, so this task can be assessed to test different drugs' effects in used animal by the interval of one week (Dellu et al, 2000).

\subsection{Treatment}

Drugs were intraperitoneally injected to mice $40 \mathrm{~min}$ after the first trial (training), $0.2 \mathrm{~mL}$ per mouse for each injection. The second trial (retrieval) was conducted 1 hour after 10-min-training in the Y-maze.

1.4.1 Experiment 1 There were six groups in Exp.1 ( $N=8$ per group): 1) saline + saline (Saline); 2) scopolamine $(1 \mathrm{mg} / \mathrm{kg})+$ morphine $(5 \mathrm{mg} / \mathrm{kg})(\mathrm{Scop} 1+$ Mor5); 3) atropine $(0.5 \mathrm{mg} / \mathrm{kg})+$ morphine $(5 \mathrm{mg} / \mathrm{kg})($ Atro0.5+ Mor5); 4) scopolamine (1 mg/kg)+saline (Scop1); 5) atropine $(0.5 \mathrm{mg} / \mathrm{kg})+$ saline (Atro0.5); 6) morphine (5 $\mathrm{mg} / \mathrm{kg}$ ) + saline (Mor5).

The dose of morphine were chosen according to our previous study (Ma et al, 2007), which suggested morphine impaired spatial memory retrieval in mice at the dose of $5 \mathrm{mg} / \mathrm{kg}$. The doses of scopolamine and atropine were conducted following several former researches in which the drugs effectively cause amnesia in mice (Jafari et al, 2006; Kim et al, 2006; Sakata et al, 2005).

1.4.2 Experiment 2 In experiment 1, all groups showed the impairments of the spatial recognition memory retrieval except the controls. In order to clarify the interaction of the drugs, low doses of drugs' effects were tested in experiment 2 and 3.

Four groups were conducted here ( $N=8$ per group): 1) saline + saline (Saline); 2) scopolamine (0.1 $\mathrm{mg} / \mathrm{kg})+$ morphine $(1.5 \mathrm{mg} / \mathrm{kg}) \quad(\mathrm{Scop} 0.1+$ Mor1.5); 3) scopolamine $(0.1 \mathrm{mg} / \mathrm{kg}) \quad+$ saline (Scop0.1); 4) morphine $(1.5 \mathrm{mg} / \mathrm{kg})+$ saline (Mor1.5).

Morphine at lower dose of $0.5 \mathrm{mg} / \mathrm{kg}$ was used in order to confirm the potential interact between drugs. Another four groups were conducted ( $N=9,10,9,9$ respectively) : 1) saline+saline (Saline); 2) scopolamine $(0.1 \mathrm{mg} / \mathrm{kg})+$ morphine $(0.5 \mathrm{mg} / \mathrm{kg})(\mathrm{Scop} 0.1+$ Mor 0.5$) ; 3)$ scopolamine $\quad(0.1 \mathrm{mg} / \mathrm{kg})+$ saline $\quad($ Scop0.1 $) ; \quad 4)$ morphine $(0.5 \mathrm{mg} / \mathrm{kg})+$ saline (Mor0.5).

1.4.3 Experiment 3 Since morphine $1.5 \mathrm{mg} / \mathrm{kg}$ has been found enough to disturb memory retrieval in the experiment 2, so atropine $0.1 \mathrm{mg} / \mathrm{kg}$ was directly co-administrated with lower dose morphine of $0.5 \mathrm{mg} / \mathrm{kg}$ in experiment 3 .

Four groups were in Exp.3 ( $N=8,9,9,10$ respectively): 1) saline+saline (Saline); 2) atropine (0.1 $\mathrm{mg} / \mathrm{kg})+$ morphine $\quad(0.5 \mathrm{mg} / \mathrm{kg})($ Atro0.1+Mor0.5); 3) atropine $(0.1 \mathrm{mg} / \mathrm{kg})+$ saline (Atro0.1); 4) morphine $(0.5$ $\mathrm{mg} / \mathrm{kg}$ ) + saline (Mor0.5).

\subsection{Statistical analysis}

Data were expressed as: 1) percentage of duration time spent in each arm (seconds) in the 5-min-retention phase (as spatial recognition memory measure); 2) percentage of number of arm entries were used to compensate for difference of memory deficit changes between treatments; 3) the number of visits in each arm in the 5-min-retention test (as a locomotor activity index). Data were expressed as mean \pm standard error of the mean (SE) and analyzed by using the SPSS statistical software package (version 10). Differences between arms within group, and differences between groups were both considered significant at $P<0.05$. One-way ANOVA was used to analyze the difference between the three arms. Differences between groups for number of arm visits were assessed with analysis of variance (ANOVA) with repeated measures where appropriate. Post hoc between-group comparisons were completed with Fisher's least significant difference test (LSD).

\section{Results}

\subsection{Effects of morphine and scopolamine/atropine on retrieval of spatial recognition memory}

2.1.1 Percentage of duration of arm visits in the 5 minutes retention test As shown in Fig.1a, Scop1, Atro0.5, Mor5, Scop1+Mor5, and Atro0.5+Mor5 groups all performed no difference between arms as expected. (Main arm effect, $F_{(2,84)}=1.236, P=0.296$, while Saline group showed arm difference (LSD: novel arm vs. start $\operatorname{arm} P=0.026$ ).

Co-administration of low doses of morphine and scopolamine/atropine showed no difference between arms with the percentage of arm duration parameter while the single-drug administered mice still kept preference to the novel arm. (Fig. 2c, main arm effect, $F_{(2,66)}=12.993, P<0.001$, Saline group (LSD: novel arm vs. start arm $P=0.02$, novel arm vs. other arm $P=0.04$ ), Scop0.1 group (LSD: novel arm vs. start arm $P=0.008$ ), Mor0.5 group (LSD: novel arm vs. other arm $P=0.04$ ); Fig. 3a, main arm effect $F_{(2,64)}=11.051, P<0.001$, Saline group (LSD: novel arm vs. start arm $P=0.03$, novel arm vs. other arm $P=0.039$ ), Atro0.1 group (LSD: novel arm vs. other arm $P=0.013$ ), Mor0.5 group (LSD: novel arm vs. start arm $P=0.045$, novel arm vs. other arm $P=0.036$ ). 2.1.2 Percentage of number of arm visits in the 5 minutes retention test As shown in Fig. 1b, merely 
Saline and Mor5 groups showed difference between arms. (Main arm effect, $F_{(2,84)}=7.762, P=0.001$, Saline group (LSD: novel arm vs. start arm $P=0.006$, novel arm vs. other arm $P=0.036$ ), Mor5 group (LSD: novel arm vs. start arm $P=0.031$ ).

However co-administration of the low doses of drugs didn't disrupt the memory retrieval as shown in the percentage of arm visits (Fig. 2b, main arm effect, $F_{(2 \text {, }}$
${ }_{56}=16.983, \quad P<0.001, \quad$ Scop0.1+Mor1.5 group (LSD: novel arm vs. start arm $P=0.010$, novel arm vs. other arm $P=0.023)$; Fig. 2d, main arm effect, $F_{(2,66)}=31.921$, $P<0.001$, Scop0.1+Mor0.5 group (LSD: novel arm vs. start arm $P=0.013$, novel arm vs. other arm $P=0.004$ ); Fig. 3b, main arm effect, $F_{(2,64)}=60.027, P<0.001$, Atro0.1+Mor0.5 group (LSD: novel arm vs. start arm $P<0.001$, novel arm vs. other arm $P=0.010$ ). The low
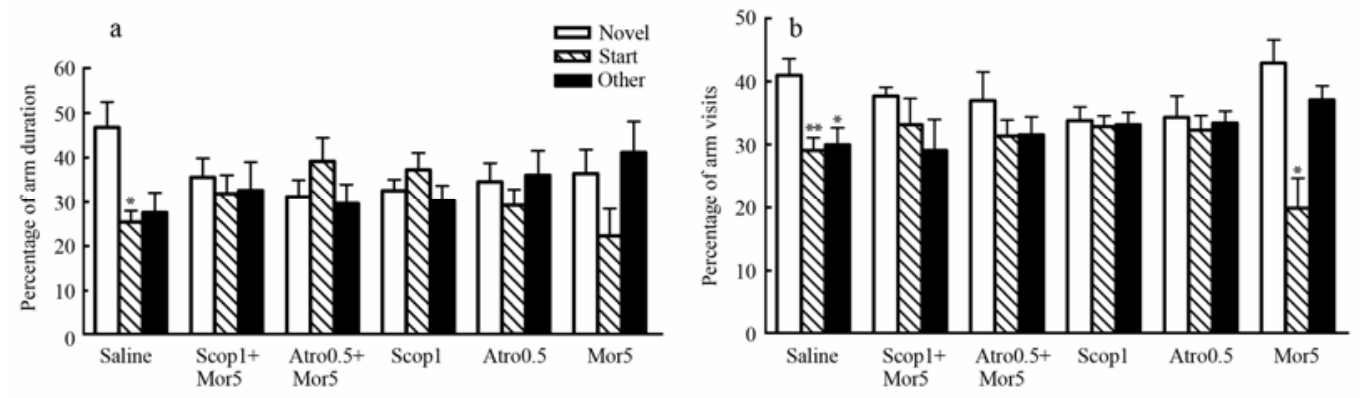

Fig. 1 Effects of pre-test co-administration of morphine and scopolamine/atropine on spatial recognition memory retrieval in mice with Y-maze

a: Only the controls showed higher percentage of arm duration of arm visits between the novel arm and the start arm within group; b: The controls showed higher percentage of the novel arm visits than the other two familiar arms. The Mor5 group showed higher percentage of the novel arm visits than the start arm.

Data were expressed as mean \pm SE. $* P<0.05,{ }^{*} P<0.01$ for difference between the novel arm and the start arm within group.
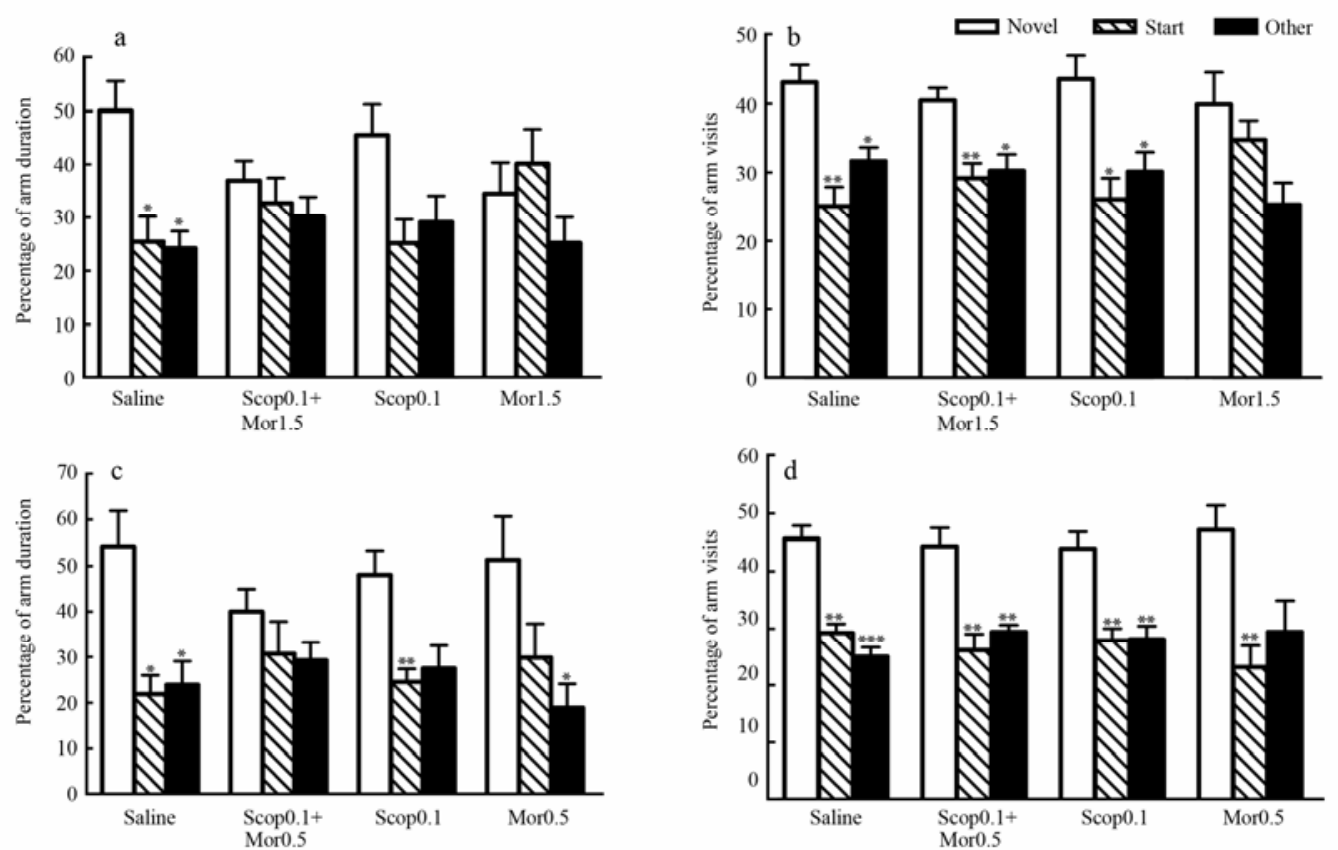

Fig. 2 Effects of pre-test low doses of morphine and scopolamine co-administration on spatial recognition memory retrieval in mice with Y-maze

a: The controls showed higher percentage of the novel arm duration than the other two familiar arms. The Scop0.1 group showed borderline higher percentage of the novel arm duration than the start arm; b: The controls, Scop0.1+Mor1.5 group and Scop0.1 group all showed higher percentage of the novel arm visits than the other two familiar arms; c: The Scop0.1+Mor0.5 group showed damaged spatial recognition memory retrieval, which was reflected by no difference was found between arms. Meanwhile other three groups all showed preference to the novel arm; d: The four groups all showed higher percentage of the novel arm visits than the other one or two familiar arms.

Data were expressed as mean \pm SE. ${ }^{*} P<0.05,{ }^{* *} P<0.01,{ }^{* * *} P<0.001$ for difference between the novel arm and the other arms within group. 
doses of drugs' single-treated mice performed distinct preference to the novel arm, except Mor1.5 group (Fig. 2c, 2d, 3b, data not shown).

\subsection{Effects of co-administration of morphine and} scopolamine/atropine on locomotor activity and the number of arm visits in the 5 minutes retention test

There was a distinct increase of number of arm visits within the scopolamine and morphine co-administrated groups except the lowest dose of the drugs in our

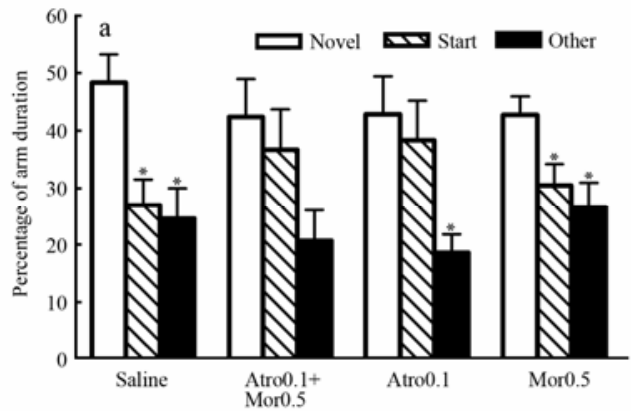

experiment. (Fig. 4a, Scop1+Mor5 vs. Saline $P=0.035$, Scop1+Mor5 vs. Atro0.5 $P=0.007$, Scop1+Mor5 vs. Mor5 $P=0.045$; Fig. 4b, Scop0.1+Mor1.5 vs. Saline $P=0.022$, Scop0.1+Mor1.5 vs. Scop0.1 $P=0.008$, Scop0.1+Mor1.5 vs. Mor1.5 $P=0.008)$. No effect on locomotor activity was found in the morphine and atropine co-administration groups (Fig. 4a,d).

\section{Discussion}

According to Dellu et al $(1992 ; 2000)$ the two

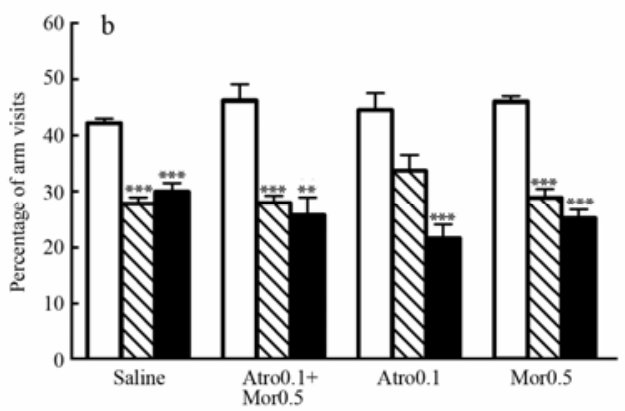

Fig. 3 Effects of pre-test low doses of morphine and atropine co-administration on spatial recognition memory retrieval in mice with Y-maze

a: The controls and Mor0.5 showed higher percentage of the novel arm duration than the other two familiar arms. The Atro0.1 group showed higher percentage of the novel arm duration than the other arm. The Atro0.1+Mor0.5 group performed damaged spatial recognition memory retrieval reflected by no difference was found between arms; $b$ : The four groups all showed higher percentage of novel arm visits than the other one or two familiar arms. Data were expressed as mean \pm SE. $* P<0.05,{ }^{* *} P<0.01,{ }^{*} * * P<0.01$ for difference between the novel arm and the other arms within group.
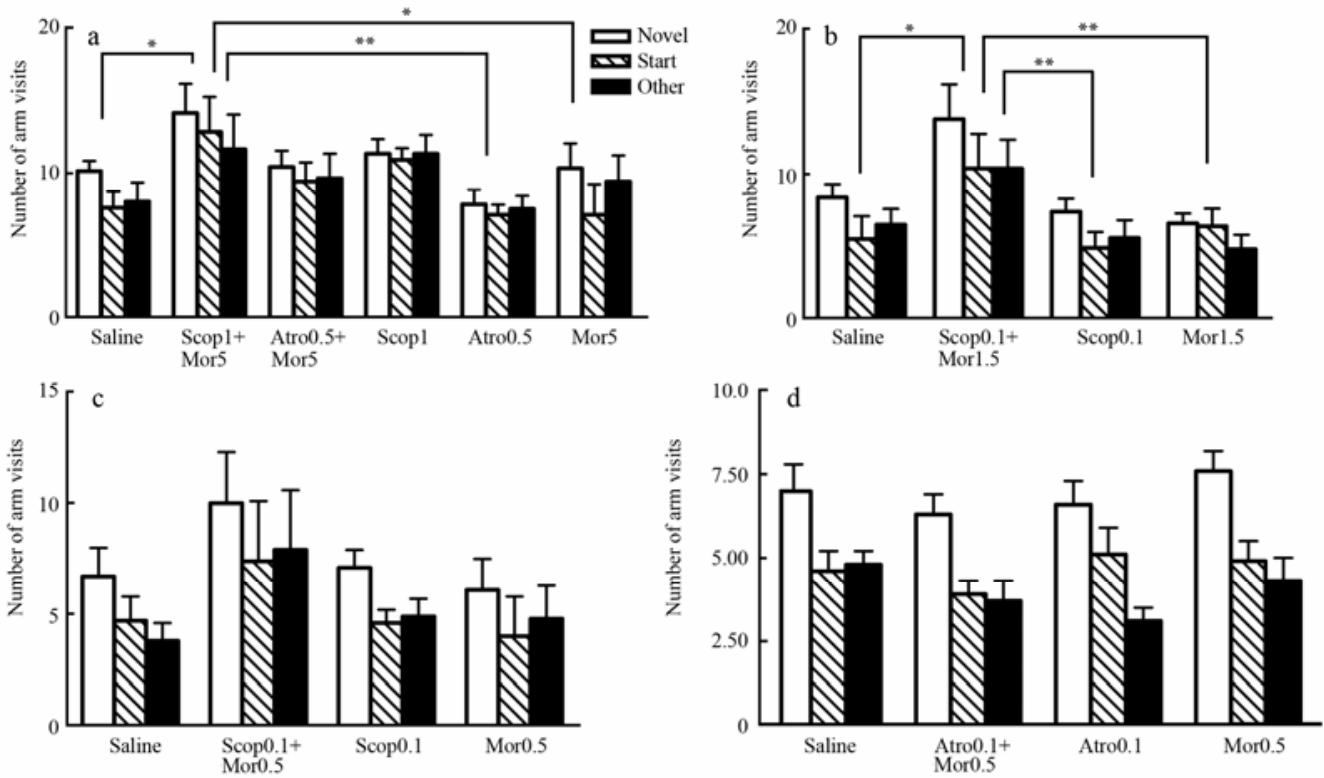

Fig. 4 Effects of co-administration of morphine and scopolamine/atropine on locomotor activity

a: The Scop1+Mor5 group showed higher number of total arm visits than the controls, Atro0.5 and Mor5 groups; b: Similar to the Scop1+Mor5 group, the Scop0.1+Mor1.5 group showed higher number of total arm visits than the other three groups; c: No difference was found between groups, while the Scop0.1+Mor0.5 group still showed the increasing trend of arm visits; d: No difference was found between groups.

Data were expressed as mean \pm SE. $* P<0.05, * * P<0.01$ for difference between groups. 
measures of exploratory behavior (inspective and inquisitive) should be separately analyzed. The duration time spent in arms is considered as the index of inspective exploratory behavior, while the number of arm visits is measured as inquisitive behavior. Our results indicated that morphine and cholinergic antagonists, scopolamine/atropine partly cooperated on impairing the inspective exploratory behavior of the spatial memory retrieval. Furthermore, it has been proved that morphine cooperated with scopolamine increased the locomotor activity.

In our data, the low doses of drugs' co-administered mice all performed impaired inspective exploratory behavior of spatial recognition memory, but still could distinguish the novel arm very well when analyzing the inquisitive behavior. The inconsistent performance of the two aspects of exploratory behavior is consistent with the observations from Conrad et al (1997) Also it has been found that amphetamine may affect the two measures towards opposite directions.(Dellu et al, 1992).

Our results were generally consistent to previous studies that atropine administration following morphine injection prevented memory retrieval in passive avoidance task (Jafari et al, 2006). Co-administration of scopolamine and morphine significantly impaired the performance of rats in Morris water maze(Zheng et al, 2002). Here we proved this interaction again in a Y-maze paradigm which characterized by both rewards and punishment free.

It was proved that there was an interaction between opioids and the cholinergic systems (Introini \& Baratti, 1984; Rush, 1986; Walker et al, 1991). Moreover injection of morphine into the medial septum could reduce $\mathrm{ACh}$ release in the hippocampus (Ragozzino \& Gold, 1995). Similarly, in vivo microdialysis has revealed that acute morphine significantly decreased the release of $\mathrm{ACh}$ in several brain regions (Arenas et al, 1990; Beani et al, 1982; Lapchak et al, 1989; Mulder et al, 1984, 1989; Rada et al, 1991). And decreasing the cholinergic functions generally caused impairment of the performance in rats' spontaneous alternation tests (McIntyre et al, 2002).

It has also been demonstrated that opioid agonists such as morphine and $\beta$-endorphine, possessing higher affinity for $\mu$-opioid receptors, inhibited cholinergic activity in the hippocampus (Decker \& McGaugh, 1991). Moreover, it has also been reported that $\mu$ and $\delta$ receptors locate on cholinergic terminals, which are normally under tonic inhibition by the opiate system (Heijna et al, 1990).

In our experiment morphine didn't show a regulary effect on the spatial recognition memory as doses were diminished. Taraschenko et al (2007) found that different doses of morphine produced a biphasic effect on extracellular acetylcholine levels, thus low and high dose of morphine (i.e., 5 and $20 \mathrm{mg} / \mathrm{kg}$ i.p.) significantly increased and decreased acetylcholine levels, respectively. These findings suggested that the morphine may not affect on the spatial memory directly and its influence on the cholinergic system were dose dependent.

With regard to the locomotor activity, we found a dramatic increase of locomotor activity in the mice co-administrated with scopolamine and morphine, which again proved that there was an interaction between the cholinergic and opiate systems. Former study demonstrated that morphine administration caused hyper-locomotor activity depending on dose and state. (Heidari et al, 2006; Ma et al, 2007; Stone et al, 1990) Increasing locomotor activity induced by morphine in rodents was thought to reflect dopamine release in the striatum (Murphy et al, 2001; Porras et al, 2003). Scopolamine was found to increase dopamine release depended on doses (Ichikawa et al, 2002), and indirectly improved locomotor activity (Bauer, 1982; Chintoh et al, 2003; Joyce \& Koob, 1981; Sakata et al, 2005) .Therefore we assumed that the hyper-locomotor activity, which was found in our experiment, was considered as the result from the cooperation of morphine and scopolamine to up-regulate the dopamine level. Atropine showed no effect on the locomotor activity both when administrating alone and co-administering with morphine. These results are consistent with previous studies using the conditioned place preference paradigm and passive avoidance test in rodents.(Jafari et al, 2006; Rezayof et al, 2007).

However, no significant locomotor increase was found in the co-administration of scopolamine 0.1 $\mathrm{mg} / \mathrm{kg}+$ morphine $0.5 \mathrm{mg} / \mathrm{kg}$ mice, which suggested the lower limit dose.

In conclusion, morphine showed interaction with cholinergic antagonists to further impair the inspective exploratory behavior of the spatial recognition memory retrieval with Y-maze paradigm. 


\section{References:}

Akwa Y, Ladurelle N, Covey DF, Baulieu EE. 2001. The synthetic enantiomer of pregnenolone sulfate is very active on memory in rats and mice, even more so than its physiological neurosteroid counterpart: distinct mechanisms? [J]. Proceedings of the National Academy of Sciences of the United States of America, 98: 14033-14037.

Arenas E, Alberch J, Sanchez AR, Marsal J. 1990. Effect of opioids on acetylcholine release evoked by $\mathrm{K}^{+}$or glutamic acid from rat neostriatal slices [J]. Brain research, 523: 51-56.

Baratti CM, Introini IB, Huygens P. 1984. Possible interaction between central cholinergic muscarinic and opioid peptidergic systems during memory consolidation in mice [J]. Behavioral and Neural Biology, 40: 155-169.

Bauer RH. 1982. Age-dependent effects of scopolamine on avoidance, locomotor activity and rearing [J]. Behavioural Brain Research, 5: 261-279.

Beani L, Bianchi C, Siniscalchi A. 1982. The effect of naloxone on opioid-induced inhibition and facilitation of acetylcholine release in brain slices [J]. British Journal of Pharmacology, 76: 393-401.

Beatty WW, Butters N, Janowsky DS. 1986. Patterns of memory failure after scopolamine treatment: implications for cholinergic hypotheses of dementia [J]. Behavioral and Neural Biology, 45: 196-211.

Castellano C, Pavone F. 1985. Dose- and strain-dependent effects of dermorphin and [D-Ala2-D-Leu5] enkephalin on passive avoidance behavior in mice [J]. Behavioral Neuroscience, 99: 1120-1127.

Chintoh A, Fulton J, Koziel N, Aziz M, Sud M, Yeomans JS. 2003. Role of cholinergic receptors in locomotion induced by scopolamine and oxotremorine-M [J]. Pharmacology, Biochemistry and Behavior, 76: 53-61.

Christensen H, Maltby N, Jorm AF, Creasey H, Broe GA. 1992. Cholinergic 'blockade' as a model of the cognitive deficits in Alzheimer's disease [J]. Brain, 115 ( Pt 6):1681-1699.

Conrad CD, Lupien SJ, Thanasoulis LC, McEwen BS. 1997. The effects of type I and type II corticosteroid receptor agonists on exploratory behavior and spatial memory in the Y-maze [J]. Brain Research, 759: 76-83.

Decker MW, McGaugh JL. 1991. The role of interactions between the cholinergic system and other neuromodulatory systems in learning and memory [J]. Synapse, 7: 151-168.

Dellu F, Contarino A, Simon H, Koob GF, Gold LH. 2000. Genetic differences in response to novelty and spatial memory using a two-trial recognition task in mice $[\mathrm{J}]$. Neurobiology of Learning and Memory, 73: 31-48.

Dellu F, Mayo W, Cherkaoui J, LeMoal M, Simon H. 1992. A two-trial memory task with automated recording: study in young and aged rats [J]. Brain Research, 588: 132-139.

Deutsch JA. 1971. The cholinergic synapse and the site of memory [J]. Science, 174: 788-794.

Drachman DA, Leavitt J. 1974. Human memory and the cholinergic system: A relationship to aging? [J] Archives of Neurology, 30: 113-121.

Ebert U, Kirch W. 1998. Scopolamine model of dementia: electroencephalogram findings and cognitive performance $[\mathrm{J}]$. European Journal of Clinical Investigation, 28: 944-949.

Heidari P, Sahebgharani M, Riazi G, Zarrindast MR. 2006. Influence of morphine and dopamine receptor sensitization on locomotor activity in mice [J]. Pharmacology, 78: 185-192.

Heijna MH, Padt M, Hogenboom F, Portoghese PS, Mulder AH, Schoffelmeer AN. 1990. Opioid receptor-mediated inhibition of dopamine and acetylcholine release from slices of rat nucleus accumbens, olfactory tubercle and frontal cortex [J]. European Journal of Pharmacology, 181: 267-278.

Ichikawa J, Chung YC, Li Z, Dai J, Meltzer HY. 2002. Cholinergic modulation of basal and amphetamine-induced dopamine release in rat medial prefrontal cortex and nucleus accumbens $[\mathrm{J}]$. Brain Research, 958: 176-184.

Introini IB, Baratti CM. 1984. The impairment of retention induced by beta-endorphin in mice may be mediated by a reduction of central cholinergic activity [J]. Behavioral and Neural Biology, 41: 152-163.

Itoh J, Ukai M, Kameyama T. 1994. Dynorphin A-(1-13) potently improves the impairment of spontaneous alternation performance induced by the mu-selective opioid receptor agonist DAMGO in mice [J]. The Journal of Pharmacology and Experimental Therapeutics, 269: 15-21.

Izquierdo I. 1980. Effect of beta-endorphin and naloxone on acquisition, memory, and retrieval of shuttle avoidance and habituation learning in rats [J]. Psychopharmacology, 69: 111-115.

Jafari MR, Zarrindast MR, Djahanguiri B. 2006. Influence of cholinergic system modulators on morphine state-dependent memory of passive avoidance in mice [J]. Physiology \& Behavior, 88: 146-151.

Joyce EM, Koob GF. 1981. Amphetamine-, scopolamine- and caffeine-induced locomotor activity following 6-hydroxydopamine lesions of the mesolimbic dopamine system [J]. Psychopharmacology, 73: 311-313.

Kahveci N, Gulec G, Ozluk K. 2006. Effects of intracerebroventricularly-injected morphine on anxiety, memory retrieval and locomotor activity in rats: involvement of vasopressinergic system and nitric oxide pathway [J]. Pharmacology, Biochemistry and Behavior, 85: 859-867.

Ketchum JS, Sidell FR, Crowell EB Jr, Aghajanian GK, Hayes AH Jr. 1973. Atropine, scopolamine, and ditran: comparative pharmacology and antagonists in man [J]. Psychopharmacologia, 28: 121-145.

Kim DH, Hung TM, Bae KH, Jung JW, Lee S, Yoon BH, Cheong JH, Ko KH, Ryu JH. 2006. Gomisin A improves scopolamine-induced memory impairment in mice [J]. European Journal of Pharmacology, 542: 129-135.

Lapchak PA, Araujo DM, Collier B. 1989. Regulation of endogenous acetylcholine release from mammalian brain slices by opiate receptors: hippocampus, striatum and cerebral cortex of guinea-pig and rat $[\mathrm{J}]$. Neuroscience, 31: 313-325.

Ma MX, Chen YM, He J, Zeng T, Wang JH. 2007. Effects of morphine and its withdrawal on Y-maze spatial recognition memory in mice $[\mathrm{J}]$. Neuroscience, 147: 1059-1065.

McIntyre CK, Pal SN, Marriott LK, Gold PE. 2002. Competition between memory systems: acetylcholine release in the hippocampus correlates negatively with good performance on an amygdala-dependent task [J]. J Neurosci, 22: 1171-1176.

Meyers B. 1965. Some effects of scopolamine on a passive avoidance response in rats [J]. Psychopharmacologia, 8: 111-119.

Mulder AH, Wardeh G, Hogenboom F, Frankhuyzen AL. 1984. Kappa- and delta-opioid receptor agonists differentially inhibit striatal dopamine and acetylcholine release [J]. Nature, 308: 278-280.

Mulder AH, Wardeh G, Hogenboom F, Frankhuyzen AL. 1989. Selectivity of various opioid peptides towards delta-, kappa; and mu-opioid receptors mediating presynaptic inhibition of neurotransmitter release in the brain [J]. Neuropeptides, 14: 99-104.

Murphy NP, Lam HA, Maidment NT. 2001. A comparison of morphine-induced locomotor activity and mesolimbic dopamine release in C57BL6, 129Sv and DBA2 mice [J]. Journal of 
Neurochemistry, 79: 626-635.

Orkin LR, Bergman PS, Nathanson M. 1956. Effect of atropine, scopolamine and meperidine on man [J]. Anesthesiology, 17: 30-37.

Patel S, Tariot PN. 1991. Pharmacologic models of Alzheimer's disease [J]. The Psychiatric Clinics of North America, 14: 287-308.

Porras G, DeDeurwaerdere P, Moison D, Spampinato U. 2003. Conditional involvement of striatal serotonin 3 receptors in the control of in vivo dopamine outflow in the rat striatum [J]. The European Journal of Neuroscience, 17: 771-781.

Rada P, Mark GP, Pothos E, Hoebel BG. 1991. Systemic morphine simultaneously decreases extracellular acetylcholine and increases dopamine in the nucleus accumbens of freely moving rats [J]. Neuropharmacology, 30: 1133-1136.

Ragozzino ME, Gold PE. 1995. Glucose injections into the medial septum reverse the effects of intraseptal morphine infusions on hippocampal acetylcholine output and memory [J]. Neuroscience, 68: 981-988.

Rezayof A, Nazari-Serenjeh F, Zarrindast MR, Sepehri H, Delphi L. 2007. Morphine-induced place preference: involvement of cholinergic receptors of the ventral tegmental area $[\mathrm{J}]$. European Journal of Pharmacology, 562: 92-102.

Rupniak NM, Steventon MJ, Field MJ, Jennings CA, Iversen SD. 1989. Comparison of the effects of four cholinomimetic agents on cognition in primates following disruption by scopolamine or by lists of objects [J]. Psychopharmacology, 99: 189-195.

Rush DK. 1986. Reversal of scopolamine-induced amnesia of passive avoidance by pre- and post-training naloxone [J]. Psychopharmacology, 89: 296-300.

Sakata Y, Chida R, Ishige K, Edagawa Y, Tadano T, Ito Y. 2005. Effect of a nutritive-tonic drink on scopolamine-induced memory impairment in mice [J]. Biological \& Pharmaceutical Bulletin, 28: 1886-1891.

Schulteis G, Martinez JL, Hruby VJ. 1988. Stimulation and antagonism of opioid delta-receptors produce opposite effects on active avoidance conditioning in mice [J]. Behavioral Neuroscience,102: 678-686.

Shiigi Y, Kaneto H. 1990. Facilitation of memory retrieval by pre-test morphine and its state dependency in the step-through type passive avoidance learning test in mice [J]. Japanese Journal of Pharmacology, 54: 79-81.

Shiigi Y, Takahashi M, Kaneto H. 1990. Facilitation of memory retrieval by pretest morphine mediated by mu but not delta and kappa opioid receptors [J]. Psychopharmacology, 102: 329-332.

Stone WS, Rudd RJ, Gold PE. 1990. Glucose and physostigmine effects on morphine- and amphetamine-induced increases in locomotor activity in mice [J]. Behavioral and Neural Biology, 54: 146-155.

Stone WS, Walser B, Gold SD, Gold PE. 1991. Scopolamine- and morphine-induced impairments of spontaneous alternation performance in mice: reversal with glucose and with cholinergic and adrenergic agonists [J]. Behavioral Neuroscience, 105: 264-271.

Sunderland T, Tariot PN, Weingartner H, Murphy DL, Newhouse PA, Mueller EA, Cohen RM. 1986. Pharmacologic modelling of Alzheimer's disease [J]. Progress in Neuro-Psychopharmacology \& Biological Psychiatry, 10: 599-610.

Taraschenko OD, Rubbinaccio HY, Shulan JM, Glick SD, Maisonneuve IM. 2007. Morphine-induced changes in acetylcholine release in the interpeduncular nucleus and relationship to changes in motor behavior in rats [J]. Neuropharmacology, 53(1): 18-26.

Walker DL, McGlynn T, Grey C, Ragozzino M, Gold PE. 1991.Naloxone modulates the behavioral effects of cholinergic agonists and antagonists [J]. Psychopharmacology, 105: 57-62.

Wesnes KA, Simpson PM, White L, Pinker S, Jertz G, Murphy M, Siegfried K. 1991. Cholinesterase inhibition in the scopolamine model of dementia [J]. Annals of the New York Academy of Sciences, 640: 268-271.

Zarrindast MR, Bananej M, Khalilzadeh A, Fazli-Tabaei S, Haeri-Rohani A, Rezayof A. 2006. Influence of intracerebroventricular administration of dopaminergic drugs on morphine state-dependent memory in the step-down passive avoidance test [J]. Neurobiology of Learning and Memory, 86: 286-292.

Zheng XG, Li XW, Yang XY, Sui N. 2002. Effects of scopolamine and physostigmine on acquisition of morphine-treated rats in Morris water maze performance [J]. Acta pharmacologica Sinica, 23: 477-480. 